\title{
Protein intake and daily activities influence to infant birth weight
}

\author{
Rossa Kurnia Ethasari ${ }^{1}$, Sapja Anantanyu ${ }^{2}$, Kusnandar ${ }^{3}$ \\ ${ }^{1}$ Human Nutrition, Nutrition Science, Pascasarjana Universitas Sebelas Maret, Indonesia \\ ${ }^{2}$ Department of counseling section, Faculty of Agriculture, Universitas Sebelas Maret, Indonesia \\ ${ }^{3}$ Department of agribusiness management, Faculty of Agriculture, Universitas Sebelas Maret, Indonesia
}

\begin{tabular}{l}
\hline Article Info \\
\hline Article history: \\
Received Oct 31, 2018 \\
Revised Dec 19, 2018 \\
Accepted Jan 26, 2019 \\
\hline
\end{tabular}

Keywords:

Daily activities

Infant birth weight

Protein intake

Pregnancy

\begin{abstract}
Pregnancy is a crucial period time of life. One of the contributing factors in pregnancy is mother's nutritional need, one of which is protein intake. A pregnant woman's protein need must be fulfilled for the health of both mother and baby. A more active lifestyle of a pregnant woman will also induce more babies' brain development than a less active one. To analyze the correlation between protein intake and daily activity with infant birth weight in third trimester pregnant women. Analytic observational using prospective Cohort design. Independent variables are protein intake and daily activities. Protein intake data is acquired from $2 \times 24$ hours food recall, daily activity is measured using Baecke questionnaire and infant birth weight is measured using a baby scale. Sample size of this study is 109 women achieved using simple random sampling. Statistic test used was Chi square test. Mean number of pregnant women's protein intake per day is $0,68 \pm 0,469 \mathrm{gr}$. Bivariate test result shows a significant correlation between protein intake and infant birth weight $(p=0.000)$ and a significant correlation between daily activities and infant birth weight $(\mathrm{p}=0.000)$. There is a correlation between protein intakes with infant birth weight in third trimester pregnant women, and there is a correlation between daily activities with infant birth weight in third trimester pregnant women.
\end{abstract}

Copyright $@ 2019$ Institute of Advanced Engineering and Science. All rights reserved.

\section{Corresponding Author:}

Rossa Kurnia Ethasari,

Human Nutrition, Nutrition Science Master Program, Sebelas Maret University, Jl. Ir. Sutami No.36A Surakarta, Central Java 57126, Indonesia.

Email: goldyrossa@gmail.com

\section{INTRODUCTION}

Mother and child health problems are still an unsolved issue in health industry, this can be seen from Infant Mortality Rate and Mother Mortality Rate which is two indicators used to measure community's health level. Infant Mortality Rate is the number of death of children aged 0-11 months compared to the number of live births. In 2013 the infant mortality rate was 11.8 per 1,000 live births and it increased to 14.9 per 1,000 live births in 2014. When compared to MDGs target of 23 deaths per 1,000 live births in 2015, Yogyakarta District had achieved this target, in other area; one of those was in Bantul District. There were still found infant mortality rate of 7.65 per 1,000 live births, which would cause some problems, one of which was low birth weight [1]. The increase of infant mortality rate shows that the effort to reduce the number of infant death hasn't reached optimal results. The causes of infant death are very complex, not only due to medical or health services factors, but also influenced by socioeconomic, culture, and religious factors [2]. Infant death can also be caused by nutritional problems.

Those nutritional problems can be measured from the nutrition status during pregnancy and can have negative impacts to pregnant mothers and their babies, such as infant low birth weight. Infant birth weight reflects the mother's health condition during pregnancy. Infant birth weight is generally used as a benchmark of maturity and is a determining factor of child's life sustainability and development [3-4]. 
Stillbirth and low birth weight are until now remaining as a major problem in the world, causing debility and death in newborns. More than 20 million infant births or $15.5 \%$ of all births are low-weight birth and $95 \%$ of them occur in developing countries, $11.6 \%$ of the world's low-weight births occur in Southeast Asia [5]. This fact means one of seven babies is born with low weight [6]. The number of low birth weight in Indonesia decreased from $11.1 \%$ to $10.2 \%$ in 2013. Daerah Istimewa Yogyakarta (DIY) was ranked third nationally of the proporsion of children with birth weight $<2,500$ grams and birth length $<48 \mathrm{~cm}$. Observed from Ante-Natal Care (ANC) coverage, DIY was ranked second under Bali and had the highest obedience rate of iron tablet consumption (Riskesdas, 2013). D.I Yogyakarta health and social welfare office stated that in 2016 the rate of low birth weight was 5.20\% [1].

Many factors contribute to low birth weight, one of which is nutrition intake. A pregnant mother has to take care of her health by consuming nutritious food. It is important to ensure a pregnant mother's macro and micronutrients intake, which are very important for enzyme and hormone production, biologic processes regulation, fetus growth and development, immunologic and reproductive systems, and also to fulfill nutrient needs during pregnancy [7-8].

One of the macronutrients needed during pregnancy is protein. Protein acts as a catalyst in heme synthesis. Protein works in iron transport to bone marrow to produce new hemoglobin and tissues for the placenta and fetus, cell growth and differentiation and blood supply formation [9]. Micronutrients needed during pregnancy are vitamin A, zinc, folic acid and iron. Iron deficiency often occurs during pregnancy, thus needing attention due to its importance in the formation of hemoglobin, which acts to transport oxygen from the lungs to other tissues. Iron deficiency causes a decrease in hemoglobin level resulting anemia in pregnant mothers which will contribute to low birth weight, prematurity, prenatal mortality and Intra Uterine Growth Retardation (IUGR) [10-11]. An anemic mother can also induce a low level of hemoglobin in the newborn, detaining the baby's growth and development [12].

Many factors contribute to low birth weight, one of which is mother's physical activity, which comprises of activities during working hours, rest, and leisure time. An active pregnant mother will induce more fetuses' brain development than the less active mothers. But, a pregnant woman's activity level has to be balanced by nutrition intake to compensate the energy used during activity. A pregnant mother also needs to reduce excessive physical activity which will affect the fetus' development [13]. For example in Bantul District, most of the women work, as farmers (11.47\%), merchants (39.63\%) and employees (25.28\%) [14]. Some older studies had analyzed the effect of physical activity level to pregnancy, such as the effects to birth weight, pregnancy span and complications occurring during labor [13]. Regarding that, this current study aims to analyze the correlation between protein intake and daily activity with infant birth weight in third trimester pregnant women.

\section{RESEARCH METHOD}

The method used in this study was analytic observational using a prospective Cohort design. The study was conducted in three months. It was starting from July to September 2018 at Bantul District Community Health Centers (Puskesmas), comprising Srandakan health center, Banguntapan 1 Health Center, Bambanglipuro Health Center, Pundong Health Center and Pleret Health Center.

Research population was 109 third trimester pregnant women aged 20-35 years old. Samples were determined using simple random sampling technique by conducting a random sampling of third trimester pregnant women in the health centers to obtain sample size of 22 pregnant women per health center. Inclusion criteria were: pregnant women willing to be research subjects, healthy pregnant women during data collection, third trimester pregnant women checking their pregnancies at Bantul District Health Centers and pregnant women without food allergy. Exclusion criteria were: double pregnancies, pregnancy with co morbidities (diabetes mellitus, hypertension), third trimester pregnant women who moved away, anemic pregnant women/KEK, pregnant women and fetuses who passed away, pregnant women who couldn't recall the food consumed.

The data collected were: Sample characteristics, comprising of mother's age, pregnancy age, mother's education, and mother's vocation. Protein intake was determined by conducting interviews by enumerator using food recall $2 \times 24$ hours questionnaire. Protein intake was then categorized into two groups: enough ( $\geq 86$ grams for mothers aged 20-29 years old and $\geq 87$ grams for mothers aged 30-35 years old) and less ( $<86$ grams for mothers aged 20-29 years old and $<87$ grams for mothers aged 30-35 years old) [15]. Daily activity was determined from interviews using Baecke questionnaire and infant birth weight was measured by competent practitioneers using baby scale with the accuracy of $0.1 \mathrm{~kg}$.

The data collected were then gradually analyzed using: univariate and bivariate analyses. Bivariate analysis used Chi square test, which is used to test categorical variable differences. The statistical tests were categorized as significant when $\mathrm{p}$ score $<0.05$. Ethical approval and clearance was obtained from 
the health research ethics committee of faculty of medicine, Sebelas Maret University. This research had already gotten ethical clearance in registration number 106/un27.6/KEPK/2018.

\section{RESULTS AND ANALYSIS}

This study was conducted at five health centers in Bantul district: Puskesmas Srandakan, Puskesmas Banguntapan 1, Puskesmas Bambanglipuro, Puskesmas Pundong dan Puskesmas Pleret. These five health centers were chosen because they were health centers with the most birth rate in Bantul district. Subjects in these health centers were analyzed to achieve study subjects characteristics data, shown in Table 1.

Table 1. Subject characteristics

\begin{tabular}{|c|c|c|}
\hline Characteristics of Mothers & $\mathrm{n}(\%)$ & Mean \pm SD \\
\hline Age (years) & & $26.61 \pm 3.550$ \\
\hline \multicolumn{3}{|l|}{ Parity } \\
\hline$<1$ time & $57(52.3)$ & \\
\hline$\geq 1$ time & $52(47.7)$ & \\
\hline \multicolumn{3}{|l|}{ Distance of Pregnancy } \\
\hline Not Risky & $67(61.5)$ & \\
\hline Risky & $42(38.5)$ & \\
\hline LILA & & $26.75 \pm 1.603$ \\
\hline \multicolumn{3}{|l|}{ Vocation } \\
\hline Laborer & $10(9.2)$ & \\
\hline Teacher & $3(2.8)$ & \\
\hline Housewife & $15(13.8)$ & \\
\hline Employee & $55(50.5)$ & \\
\hline Farmer & $10(9.2)$ & \\
\hline Merchant Education & $16(14.7)$ & \\
\hline Elementary school & $7(6.4)$ & \\
\hline Junior high school & $19(17.4)$ & \\
\hline Senior high school & $41(37.6)$ & \\
\hline Diploma & $21(19.3)$ & \\
\hline Undergraduate & $21(19.3)$ & \\
\hline \multicolumn{3}{|l|}{ Income } \\
\hline$<1,000,000$ & $4(3.7)$ & \\
\hline $1,000,000-2,000,000$ & $86(78.8)$ & \\
\hline$>2,000,000$ & $29(17.3)$ & \\
\hline
\end{tabular}

This research's study subjects are third trimester pregnant women aged 20-35 years old. The mean number of third trimester pregnant women in this study was $26.61 \pm 3.55$ years old and the mean number of LILA was $26.75 \pm 1.603 \mathrm{~cm}$. Pregnant women with multigravida parity ( $\geq 1$ time) was $47.7 \%$. Distances of pregnancy were risky $38.5 \%$ and not risky $61.5 \%$. Most pregnant women work as employees $(50.5 \%)$ with medium income $(78.8 \%)$ and most of their education was senior high school $(37.6 \%)$ with the most income of $\operatorname{Rp} 1,000,000-\operatorname{Rp} 2,000,000(78.8 \%)$. Correlation between protein intake and daily activity and infant birth weight are shown in Table 2.

Table 2. Correlation between protein intake and daily activity and infant birth weight

\begin{tabular}{cccccc}
\hline Variable & $\begin{array}{c}\text { Infant Birth Weight } \\
\text { Low } \\
{[\mathrm{n}(\%]}\end{array}$ & $\begin{array}{c}\text { Normal } \\
{[\mathrm{n}(\%)]}\end{array}$ & Total & $R R$ & $p$-value \\
\hline Protein Intake & & & & 0.089 & $\mathrm{P}<0.001$ \\
Less & $32(91.4)$ & $3(4.1)$ & 35 & & \\
Enough & $3(8.6)$ & $71(95.9)$ & 74 & & \\
Total & $35(100)$ & $74(100)$ & 109 & 2.766 & $\mathrm{P}<0.001$ \\
Daily Activities & & & & & \\
Light & $5(14.3)$ & $60(79.7)$ & 64 & & \\
Heavy & $30(85.7)$ & $15(20.3)$ & 45 & & \\
Total & $35(100)$ & $74(100)$ & 109 & & \\
\hline
\end{tabular}

Source : Primary Data (2018)

Bivariate test results using Chi-square test shows a significant correlation between pregnant women's protein intake and infant birth weight ( $p=0.000, \mathrm{RR}=0.08995 \% \mathrm{CI}=0.030-0.264)$. This result aligns 
with a study by [16] that shows the importance of protein intake during pregnancy, in which a pregnant woman's protein needs will increase. Protein works to support cell development in mothers and fetuses and also to transport iron in the form transferrin. Less protein intake causes low birth weight because during pregnancy, protein is needed by placenta to transport nutrients to fetus, to synthesize hormones and enzymes in mothers and fetuses, and also less protein intake induces smaller placenta and smaller organ size development. Blood volume of the mother will decrease and cardiac output will not be adequate. This leads to decreasing blood flow to placenta which then causes less nutrient transfer that will inhibit fetus development thus causing low birth weight [17]. Table 2 shows a high rate of infant low birth weight in Bantul district health centers $(91.4 \%)$. This study aligns with other study which states that a low protein intake in third trimester pregnancy causes low birth weight [18].

Table 2 also shows a significant correlation between daily activity and infant birth weight ( $\mathrm{p}=0.000, \mathrm{RR}=2.766$ 95\% $\mathrm{CI}=1.818-4.206$ ). This result aligns with another study [19] that shows a significant correlation between physical work demands and premature and low-weight births. In their study also conclude that pregnant women with heavy physical activity affect infant birth weight [20]. Other studies have also reported opposite results about the effect of pregnant woman's activities: standing, repeated bending, ladder climbing, and lifting heavy objects during pregnancy, to fetus development, premature birth, and other obstetric complications. Physical activity can increase uteric activity (contraction). Women with a risk of premature labor are suggested to decrease their activities in second and third trimesters of pregnancy [21].

Physical activity increases catecholamine release that can induce uteric contraction. During pregnancy, it was found that catecholamine levels increased in women experiencing work stress. The increase of catecholamine during pregnancy causes the decrease of uteric blood flow [22-23]. Numerous hormones, including Corticotropin Releasing Hormone $(\mathrm{CRH})$, adernocorticotropin releasing hormone (ACTH), cortisol, and (nor) adrenaline, are released in large amounts into blood flow. These hormones mediates uteric contraction, leading to premature labor and affecting birth weight [24]

\section{CONCLUSION}

According to study results, it is concluded that there is a significant correlation between protein intake and infant birth weight in third trimester pregnant women ( $p=0.000, \mathrm{RR}=0.089$ 95\% CI: 0.030-0.264). There is a significant correlation between daily activity and infant birth weight in third trimester pregnant women $(p=0.000, \mathrm{RR}=2.76695 \% \mathrm{CI}=1.818-4.206)$. This study expects to give information and knowledge to pregnant women to ensure enough protein intake and daily activities during pregnancy to induce normal birth weight and optimum and healthy infant development. This study also expects to emphasize the importance of nutritious food to maintain pregnant women's health status.

\section{ACKNOWLEDGEMENTS}

Authors would like to thank to health center (Puskesmas) Srandakan, Puskesmas Banguntapan 1, Puskesmas Bambanglipuro, Puskesmas Pundong and Puskesmas Pleret, supervisors, parents and friends.

\section{REFERENCES}

[1] Bantul District Health Office, "Bantul Regency Health Profile in 2017". Yogyakarta, Bantul District Health Office, December 2017 (in Bahasa: Dinas Kesehatan Kabupaten Bantul, "Profil Kesehatan Kabupaten Bantul Tahun 2017”. Yogyakarta, Dinas Kesehatan Kabupaten Bantul, December 2017.

[2] DIY Health Service, "Yogyakarta City Health Profile in 2016", Yogyakarta, DIY Health Service, December 2016 (in Bahasa: Dinas Kesehatan DIY, "Profil Kesehatan Kota Yogyakarta Tahun 2016", Yogyakarta, Dinas Kesehatan DIY, December 2016.

[3] Gill, et al., "Birth and Developmental Correlates Of Birth Weight In A Sample Of Children With Potential Sensory Processing Disorder," BMC Pediatrics, vol. 13, no. 29, pp. 1-8, 2013.

[4] Agarwal, K., Agarwal, A., Agrawal, V. K,, Agrawal, P., Chaudhary, V., " Prevalence and determinants of low birth weight among institutional deliveries," Annals of Nigerian Medicine, vol. 5, no. 2, pp. 48-52, 2012.

[5] Kayode, A.G., Coleman-Amoakoh, M., Agyepakon, Ansah, E., Grobbee, E. D., Grobusch-Klipstein, K. "Contextual Risk Factor for Low Birth Weight: A Multilevel Analysis,” Plos One Journal, vol. 9, no. 10, pp. 1-8, 2014.

[6] World Health Organization (WHO), Global Nutrition Targets 2025: Low Birth Weight Policy Brief. Geneva: World Health Organization, Februari 2014. 
[7] Sharma S and Mishra S. "Maternal risk factors and consequences of low birth weight in Infants," IOSR Journal Of Humanities And Social Science (IOSR-JHSS), vol. 13, no. 4, pp. 39-45, 2013.

[8] Paneru, D.P., Naik, V.A., Nilgar, B., Mallapur MD., "Obstetric risk factors for low birth weight amongst full term infants born at a tertiary care hospital of Belgaum District, South India," Community Med, vol.5, no.1, pp.81-84, 2014.

[9] Mahenaz, A and Ismail, H. "Severe Anemia during Late Pregnancy," Hindawi Publishing Corporation Case Reports in Obstetrica and Gynecology, volume 2012, Article ID 485452, 3 pages.

[10] Ministry of Health. 2014. Infodatin: Maternal Health Situation. Jakarta: Ministry of Health (in Bahasa: Kementerian Kesehatan. 2014. Infodatin: Situasi Kesehatan Ibu. Jakarta: Kementerian Kesehatan).

[11] Rao, S., Chittaranjan, S., Yajnik, Asawari, K., Caroline. "Nutritional intake of micronutrient- rich foods in rural Indian mothers is associated with the size of the babies at birth,"The Journal of Nutrition, vol.131, no. 4, pp. 121724, 2013.

[12] Kolte, D, Sharma, R, Vali, S. "Correlates between micronutrient intake of pregnant women and birth weight of infant from Central India," The Internet Journal of Nutrition and Wellnees, vol. 8, no. 2, pp. 1-9, 2009.

[13] Khaula and Endang Alchadi, "Maternal Nutrition Status and Infant Birth Weight," Department of Public Health Nutrition, Faculty of Public Health, University of Indonesia. National Public Health Journal, vol. 7, no. 3, pp. 1-9, 2012 (in Bahasa: "Status Gizi Ibu dan Berat Badan Lahir Bayi,” Departemen Gizi Kesehatan Masyarakat Fakultas Kesehatan Masyarakat Universitas Indonesia. Jurnal Kesehatan Masyarakat Nasional, vol. 7, no. 3, pp. 1-9, 2012).

[14] Bantul Regency Central Bureau of Statistics, 2017. "Bantul in Figures. Bantul " (in Bahasa: Badan Pusat Statistik Kabupaten Bantul, 2017. "Bantul Dalam Angka. Bantul), Yogyakarta

[15] Indonesian Ministry of Health. "Regulation of the Minister of Health of the Republic of Indonesia Number 75 of 2013 concerning the recommended number of nutritional adequacy for the Indonesian people". Ministry of Health of the Republic of Indonesia. Jakarta, p.10, December 2013, (in Bahasa: Kementrian Kesehatan RI. "Peraturan Menteri Kesehatan Republik Indonesia Nomor 75 Tahun 2013 tentang angka kecukupan gizi yang dianjurkan bagi bangsa Indonesia”. Kementerian Kesehatan Republik Indonesia. Jakarta, hal.10, December 2013).

[16] Ba'ul, Setyawati, "Differences in Protein Intake, Iron, Folic Acid and Vitamin B12 Between III Trimester Pregnant Women Anemia and No Anemia at Tanggungharjo Health Center in Grobogan Regency," Journal of Nutrition College, vol. 3, no. 1, pp. 228-234, 2014, (in Bahasa: "Perbedaan Asupan Protein, Zat Besi, Asam Folat dan Vitamin B12 Antara Ibu Hamil Trimester III Anemia dan Tidak Anemia Di Puskesmas Tanggungharjo Kabupaten Grobogan," Journal of Nutrition College, vol.3, no. 1, pp. 228-234, 2014).

[17] Rolfes, S.R., Pinna, K., Whitney, E. "Understanding normal and clinical nutrition". Eight edition. USA: Wadsword, 2009. pp. 338-342, 442-451, 477-500.

[18] Khoushabi, F., Saraswathi, G. "Assosiation between maternal nutrition status and birth weight of neonates in selected hospitals in mysore city india," Pakistan Journal of Nutrition, vol. 9, no. 12, pp. 1124-1130, 2010.

[19] Niedhammer, et al., "Occupational predictors of pregnancy outcomes in Irish working women in the Lifeways cohort," An International Journal of Obstetrics and Gynaecology on birth weight and other pregnancy outcomes. BJOG, vol.11, no. 6, pp. 943-952, 2009.

[20] Aminian, et al., "Association between maternal work activity on birth weight and gestational age," Asian Pacific Journal of Reproduction, vol. 3, no. 3, pp. 200-203, 2014.

[21] Khojasteh, et al., "The Relationship between Maternal Employment Status and Pregnancy Outcomes," Global Journal of Health Science, vol. 8, no. 9, pp. 37-43, 2016.

[22] Jukic, A.M. Zaura. "Factors correlated with physical activity during pregnancy and associations of physical activity with spontaneous abortion, length of gestation, and birthweight," Matern Child Health J, vol. 16, no. 5, pp. 10311044, 2012.

[23] Rakers F, Bischoff S, Schiffner R, et al., "Role of catecholamines in maternal-fetal stress transfer in sheep," Am J Obstet Gynecol, vol. 213, no. pp. 684.e1-684.e9, 2015.

[24] Jayakodi, et al., "Effect of Physical Activity During Pregnancy on Birth Outcomes in Mothers Presenting at the Antenatal Clinic of De Soysa Maternity Hospital, Colombo 08," Asia Pacific Journal of Multidisciplinary Research, vol. 3, no. 2, pp. 76-82, 2015. 